\title{
A study on umbilical cord blood cardiac troponin $T$ as an early predictor of myocardial ischaemia in perinatal asphyxiated newborns
}

\author{
C Anitha ${ }^{1}$, *M Santhosh Kumar ${ }^{2}$, G M Ramya ${ }^{4}$
}

Sri Lanka Journal of Child Health, 2019 ; 48(2): 152- 154

\begin{abstract}
Objectives: To predict the occurrence of myocardial ischaemia in the first 72 hours of life in perinatal asphyxiated newborns by estimating cord blood cardiac troponin $\mathrm{T}$.
\end{abstract}

Method: Fifty newborns with Apgar scores $\leq 6$ at 5 minutes of birth from October 2012 to October 2014 were included in the study. Cord blood samples of those babies were taken for estimation of cardiac troponin $\mathrm{T}$ (cTnT) by the Immunoassay Elecsys Troponin T STAT (Roche) method. Umbilical cord blood cTnT level above $0.097 \mathrm{ng} / \mathrm{ml}$ was considered as positive. Further, those newborns were managed in the neonatal intensive care unit (NICU) according to severity and monitored for hypotension with requirement of inotropes. In the next 72 hours those who required inotropes were screened for myocardial ischaemia by electrocardiogram (ECG) and echocardiogram (ECHO).

Results: Out of the 50 cases, 45 developed myocardial ischaemia and cord blood was positive for cTnT in 40 cases which was statistically very significant $(p=0.0001)$. Further, when comparison was done between Group A (moderate asphyxia) and Group B (severe asphyxia), there was no statistical significance $(p=0.57)$.

Conclusions: Irrespective of the severity of perinatal asphyxia, cord blood cTnT $>0.09 \mathrm{ng} / \mathrm{ml}$ will help to predict occurrence of myocardial ischaemia in the first 72 hours of life in perinatal asphyxiated newborns.

DOI: http://dx.doi.org/10.4038/sljch.v48i2.8711

\begin{tabular}{l}
\hline${ }^{1}$ Associate Professor, ${ }^{2}$ Assistant Professor, \\
${ }^{3}$ Postgraduate in Paediatrics, Department of \\
Paediatrics, JSS Medical College and Hospital, JSS \\
AHER, Mysore, Karnataka, India \\
${ }^{*}$ Correspondence: santhosh.kumar94@yahoo.com
\end{tabular}

https://orcid.org/0000-0002-5562-8810

(Received on 30 June 2018: Accepted after revision on 17 August 2018)

The authors declare that there are no conflicts of interest Personal funding was used for the project.

Open Access Article published under the Creative Commons Attribution CC-BY License
(Key words: Perinatal asphyxia, cord blood cardiac troponin T, myocardial ischaemia, ECG, ECHO)

\section{Introduction}

In India, between 250,000 to 350,000 infants die each year due to perinatal asphyxia (PA), mostly within the first three days of life ${ }^{1}$. PA affects all systems of the neonate, but the most vulnerable are the central nervous system (CNS), gastrointestinal tract (GIT) and cardiac ${ }^{2}$. Myocardial ischaemia secondary to PA can be assessed clinically and by electrocardiogram (ECG), echocardiogram (ECHO) and cardiac enzyme estimation in the serum $^{3}$. Several studies have been done on serum cardiac troponin-t levels in relation to PA, but in this study we have focused on umbilical cord blood cardiac troponin $\mathrm{T}$ levels in relation to PA for which limited studies are available.

\section{Method}

A hospital based prospective study was designed to include 50 neonates with Apgar scores of $\leq 6$ at 5 minutes of birth from October 2012 to October 2014. Neonates with congenital cardiac/CNS anomalies, born to mothers with suspected infection/sepsis were excluded. After neonatal resuscitation, cord blood samples were taken and further management continued in the neonatal intensive care unit (NICU) as per protocol. It was ensured that cord blood samples reached the biochemical laboratory within 30 minutes. Cord blood samples were estimated for cardiac troponin $\mathrm{T}$ levels by the Immunoassay Elecsys Troponin $\mathrm{T}$ STAT (Roche) method. Umbilical cord blood cardiac troponin T (cTnT) level $>0.097 \mathrm{ng} / \mathrm{ml}$ was considered as positive. All 50 newborns treated in NICU were followed up for 72 hours. Those having circulatory shock with requirement of inotropes (clinical myocardial ischaemia) were screened for myocardial ischaemia by ECG and ECHO. Newborns showing changes either in ECG or ECHO were considered to be having myocardial ischaemic damage secondary to PA.

\section{Results}

Of the 50 newborns with APGAR scores of $\leq 6$ at 5 minutes of birth, 45 had moderate PA (APGAR $>3$ $\& \leq 6)$ and 5 had severe PA (APGAR $\leq 3)^{4}$ as shown in Table 1.

In the next 72 hours of NICU admission, 40 with moderate PA (group A) and all 5 with severe PA 
(group B) newborns developed myocardial ischaemic features both clinically and by ECG/ECHO. All 45 myocardial ischaemic neonates had cardiac and respiratory failure with ECG changes but only 35 developed ECHO changes, with right ventricular hypokinesia being the commonest finding (Table 2).

Table 1: Distribution of perinatally asphyxiated newborns

\begin{tabular}{|l|c|c|}
\hline \multicolumn{1}{|c|}{ Severity of asphyxia } & Number (\%) of neonates & Group \\
\hline Moderate & $45(90 \%)$ & A \\
\hline Severe & $05\left(10^{\wedge}\right)$ & B \\
\hline
\end{tabular}

Table 2: Summary of clinical manifestations, ECG changes and ECHO changes of myocardial ischaemia in perinatally asphyxiated neonates

\begin{tabular}{|l|c|c|c|}
\hline \multicolumn{1}{|c|}{ Category } & Group A (n=40) & Group B (n=5) & Total (n=45) \\
\hline Clinical findings & & & \\
Respiratory failure & $40(100 \%)$ & $05(100 \%)$ & $45(100 \%)$ \\
Cardiac failure & $40(100 \%)$ & $05(100 \%)$ & $45(100 \%)$ \\
\hline ECG changes & $25(62.5 \%)$ & $00(00 \%)$ & $25(55.5 \%)$ \\
Grade I & $07(17.5 \%)$ & $01(20 \%)$ & $08(17.8 \%)$ \\
Grade II & $05(12.5 \%)$ & $03(60 \%)$ & $08(17.8 \%)$ \\
Grade III & $03(07.5 \%)$ & $01(20 \%)$ & $04(08.9 \%)$ \\
Grade IV & 18 & & $23(51.1 \%)$ \\
\hline ECHO changes & 05 & 05 & $10(22.2 \%)$ \\
RV hypokinesia & 10 & 05 & $14(31.1 \%)$ \\
LV hypokinesia & 03 & 04 & $07(15.6 \%)$ \\
Tricuspid regurgitation & 00 & 04 & $03(06.7 \%)$ \\
Pulmonary hypertension & & 03 & \\
RA/RV dilatation & & & \\
\hline
\end{tabular}

$R V:$ Right ventricular, LV: Left ventricular, RA: Right atrial

Out of 50 samples of cord blood for cardiac troponin $\mathrm{T}, 40$ were positive, with a median of $0.18 \mathrm{ng} / \mathrm{ml}$ and a highest of $0.4 \mathrm{ng} / \mathrm{ml}$. There was a significant association, as per Fischer exact test calculator, between cord blood cardiac troponin $\mathrm{T}$ being positive and occurrence of myocardial ischaemia in the first 72 hours in those neonates $(p=0.0001)$. Further, in group A (45 neonates) 40 developed myocardial ischaemia but cord blood cTnT was positive in 35 only. In comparison, all group B neonates developed myocardial ischaemia and were also positive for cTnT. The correlation between cord blood cTnT being positive and development of myocardial ischaemia in the first 72 hours of life in group A and group B is shown in Table 3.

Table 3: Correlation between cord blood cardiac troponin $T(c T n T)$ level being positive and development of myocardial ischaemia in the first 72 hours of life in group $A$ and group $B$

\begin{tabular}{|l|c|c|c|}
\hline \multicolumn{1}{|c|}{ Group } & Cord blood cTnT & $\begin{array}{c}\text { Myocardial ischaemia positive in } \\
\text { first 72 hours of life }\end{array}$ & P value \\
\hline A (45) & 35 & 40 & 0.57 \\
\hline B (05) & 05 & 05 & \\
\hline
\end{tabular}

\section{Discussion}

In the present study, we wanted to find out whether cord blood cTnT estimation will help predict myocardial ischaemia in PA newborns in the first 72 hours of life. In adults, elevation of cardiac enzymes in the serum is a well-established fact during myocardial ischaemia. However, in neonates it is still a debatable topic with studies showing different results. Trevidanuto $\mathrm{D}$ et al initially studied the role of Troponin I and CK-MB in PA newborns ${ }^{5}$. Later, Karnik et al compared troponin I and CK -MB in PA newborns, which showed troponin I being more predictive than CK-MB of myocardial ischaemia ${ }^{6}$. Later, cTnT came under research trial. Costa et al and Marta et al studies showed significant elevation of cTnT in serum of PA neonates ${ }^{7}$. Rajkumar et al proved that serum cTnT is better than CK-MB in predicting myocardial ischaemia in PA neonates ${ }^{8}$. Clark et al also showed positive correlation between serum cTnT level and severity of $\mathrm{PA}^{9}$. Joseph et al estimated the serum of PA neonates at 4 hours for cTnT and concluded that it helps in predicting myocardial ischaemia ${ }^{10}$. Tamilarasu $\mathrm{N}$ et al also concluded that cTnT screening will help in predicting myocardial ischaemia in PA neonates ${ }^{11}$.

With the above background we tried to see whether cord blood cTnT levels of PA neonates will help to predict myocardial ischaemia in the first 72 hours of 
life. While all studies have taken serum of neonates for estimating cTnT, we have taken cord blood serum and we also tried to prove myocardial ischaemia by ECG and ECHO. Our study showed that elevated cord blood cTnT $(>0.09 \mathrm{ng} / \mathrm{ml})$ will predict the occurrence of myocardial ischaemia in the next 72 hours of life in PA neonates. Further, our study showed that the severity of PA will not influence predictability of myocardial ischaemia in the first 72 hours of life by cord blood cTnT estimation (Table 3). One limitation of this study is that matched controls were not used.

\section{Conclusions}

Irrespective of severity of PA, cord blood cTnT $>0.09 \mathrm{ng} / \mathrm{ml}$ will help to predict occurrence of myocardial ischaemia in the first 72 hours of life in perinatally asphyxiated newborns.

\section{References}

1. Caliskan E, Doger E, Cakiroglu Y, Duman C, TurkerG, Yucesoy I. Cord blood cardiac troponin I and creatine kinase MB levels in poor neonatal outcomes. Journal of the Turkish-German Gynecological Association 2006; 7:98-102.

2. Araujo K, Da Silva J, Sanudo A, Kopelman B. Plasma concentrations of cardiac troponin I in newborn infants. Clinical Chemistry 2004; 50:1717-18.

https://doi.org/10.1373/clinchem.2004.0334 72

PMid: 15331524

3. Baum H, Hinze A, Bartels P, Neumeier D. Reference values for cardiac troponins $\mathrm{T}$ and I in healthy neonates. Clinical Biochemistry 2004; 37:1079-82.

https://doi.org/10.1016/j.clinbiochem.2004.0 8.003

PMid: 15589813

4. Shah GS, Singh R, Das BK. Outcome of newborns with birth asphyxia. Journal of the Nepal Medical Association 2005; 44(158):44-6.

PMid: 16554870

5. Trevisanuto $\mathrm{D}$, Zaninotto $\mathrm{M}$, Altinier $\mathrm{S}$, Plebani M, Zanardo V. High serum cardiac troponin $\mathrm{T}$ concentrations in preterm infants with respiratory distress syndrome. Acta Paediatrica 2000; 89:1134-6.

https://doi.org/10.1111/j.16512227.2000.tb0

3364.x

PMid: 11071098
6. Kanik E, Ozer EA, Bakiler AR, Aydinlioglu H, Dorak C, Dogrusoz B, et al. Assessment of myocardial dysfunction in neonates with hypoxic-ischaemic encephalopathy: is it a significant predictor of mortality? Journal of Maternal-Fetal and Neonatal Medicine 2009; 22:239-42.

https://doi.org/10.1080/14767050802430834 PMid: 19330708

7. Costa S, Zecca E, De Rosa G, De Luca D, Barbato G, Pardeo M, et al. Is serum troponin $\mathrm{T}$ a useful marker of myocardial damage in newborn infants with perinatal asphyxia? Acta Paediatrica 2007; 96(2):181-4. https://doi.org/10.1111/j.16512227.2007.001 04.x

PMid: 17429901

8. Rajakumar PS, Bhat BV, Sridhar MG, Balachander J, Konar BC, Narayanan P, et al. Cardiac enzyme levels in myocardial dysfunction in newborns with perinatal asphyxia. Indian Journal of Pediatrics 2008; 75:1223-5.

https://doi.org/10.1007/s12098-008-0242-Z PMid: 19190877

9. Clark SJ, Newland P, Yoxall CW, Subhedar NV. Cardiac troponin $\mathrm{T}$ in cord blood. Archives of Disease in Childhood 2001; 84:34-7.

https://doi.org/10.1136/fn.84.1.F34

PMCid: PMC1721203

10. Joseph S, Kumar S, Ahamed MZ, Lakshmi S. Cardiac troponin-T as a marker of myocardial dysfunction in term neonates with perinatal asphyxia. Indian Journal of Pediatrics 2018 Apr 14. [Epub ahead of print].

https://doi.org/10.1007/s12098-018-2667-3 PMid: 29654572

11. Tamilarasu N, Kumaravel KS. A study on cardiac troponin $t$ in early diagnosis of myocardial injury due to perinatal asphyxia and its comparison with other modalities. International Journal of Contemporary Pediatrics 2017; 4(6):2098-102. https://doi.org/10.18203/23493291.ijcp2017 4739 